\title{
Traversing the Barrier: A Journey of Insulin from Vascular Lumen into Skeletal Muscle
}

\section{Hong Wang*}

Division of Endocrinology and Metabolism, Department of Medicine, University of Virginia Health System, Charlottesville, VA 22908, USA

Plasma insulin must traverse the vascular endothelium to reach its major sites of action on myocytes and adipocytes. In study simultaneously measuring plasma and lymphatic insulin concentrations in normal, conscious dogs during euglycemic insulin clamps it was found that the steady-state plasma insulin concentration was consistently higher than lymph with a rough ratio of 3:2 during the basal period. In addition, while plasma insulin concentration rose quickly to reach the steady-state during the insulin clamp, the lymph insulin concentration rose very slowly indicating a barrier function of the vascular endothelium. Most importantly, this study showed that the dynamics of glucose disposal correlated very strikingly with the insulin concentration in lymph but not plasma, suggesting that trans-capillary insulin transport is a rate limiting step for peripheral insulin action [1]. Consistent with this, direct injection of insulin into canine skeletal muscle in vivo was recently noted to significantly hasten the onset of muscle glucose utilization compared with intravenously delivered insulin [2]. Multiple other studies also support such an important role of vascular endothelium during insulin clamp by measurement of the insulin concentration within skeletal muscle interstitium in humans and animals using either lymphatic sampling or microdialysis methods [3-7]. Results obtained using either method indicate that even after several hours of steady state hyperinsulinemia, muscle interstitial insulin concentration is only $40-50 \%$ of that in plasma and the time course for insulin-mediated glucose disposal during the euglycemic clamp correlates strongly with interstitial but not plasma insulin concentrations. Based on these findings, it has been estimated that slow trans-endothelial insulin transport may account for $30-40 \%$ of insulin resistance seen with human obesity or type-2 diabetes $[3,8,9]$.

Current evidence indicates that insulin Trans Endothelial Transport (TET) is mediated by transporting caveolae that contain or associate with multiple structural and signaling molecules including caveolin-1, Insulin Receptor (IR), IGF-1R, dynamin 2, actin filaments and eNOS [10-18]. Early studies demonstrated that vascular Endothelial Cells (ECs) express IRs and that insulin TET is saturable and mediated by IRs $[10,19,20]$. Subsequent in vivo studies also reported that at physiological insulin concentrations insulin TET into human skeletal muscle interstitium is saturable [21,22]. However, several in vivo studies were unable to observe the saturation when supraphysiological insulin doses were applied during an insulin clamp [23,24]. In 2006, we employed a different approach using confocal microscopy and serial muscle biopsies and found that intravenously infused Fluorescein Isothiocyanate (FITC)-labeled insulin rapidly localized within the vascular ECs of skeletal muscle but not in the intercellular clefts in vivo [18]. Given that vascular ECs also possess IGF-1 receptors and IGF-1Rs are $\sim 10 \mathrm{x}$ more abundant than IRs with a much lower affinity for insulin's binding we found that both IGF-1 peptide and a neutralizing antibody against IGF-1R significantly inhibited insulin uptake and TET when a pharmacologic insulin concentration (50nM) was used $[18,25,26]$. This has provided an alternative explanation for the seemingly conflicting data regarding the saturability of insulin transport into muscle, i.e. that at physiological insulin concentrations insulin TET is mediated predominantly by IRs but at supraphysiologic insulin concentrations both IR and IGF-1R (and IR/IGF-1R hybrid receptors) contribute to insulin TET [27,28]. Caveolin-1,a 21-kDa integral membrane protein required for caveolae formation is required for receptor-mediated albumin uptake by vascular ECs [29-31]. We have previously reported that antibodies against IR and caveolin-1 mutually co-immunoprecipitate one another from ECs and others have reported that IR binds to caveolin-1 scaffolding domain through its caveolin-1 binding domain $[18,32,33]$. Moreover, a recent electron microscopic immunocytochemical study has convincingly shown that IRs are present throughout in the plasma membrane but are particularly concentrated at the neck of caveolae in 3T3-L1 adipocytes [34]. IGF-1Rs appear to have similar lipid raft/caveolae localization in the plasma membrane [35]. We have reported that knockdown of caveolin-1 expression in bAECs using specific caveolin-1 siRNA reduces caveolin-1 mRNA and protein expression by $\sim 70 \%$, and reduces FITC-insulin uptake by $67 \%$, whereas over-expression of caveolin-1 increases insulin uptake. In addition, knockdown of caveolin-1 significantly reduces both insulin receptor protein level and insulin-stimulated Akt1 phosphorylation [13]. Dynamin-2 is a large GTPase that regulates caveolae-mediated endocytosis of cholera toxin and albumin by promoting the separation of caveolae from the plasma membrane via GTP hydrolysis. We have reported that dynamin-2 is also required for caveolae-mediated insulin uptake. Either inhibition of dynamin-2 function (with Dynasore) or siRNA knockdown of dynamin-2 inhibits vascular EC insulin uptake [12]. Insulin has been reported to induce rapid cortical actin filament remodeling in a variety of cell types including vascular ECs. This remodeling has been found to correlate to an increased transport of nutrients such as amino acids and glucose and caveolae-mediated macromolecules endocytosis [36-40]. We have recently reported that insulin-induced cortical actin filament remodeling in ECs is required for caveolae-mediated insulin's uptake and TET in a PI3-kinase and plasma membrane lipid rafts dependent fashion [14]. We have also reported that insulin act on vascular ECs to facilitate its own uptake and TET through multiple intracellular signaling pathways including PI-3 kinase-Akt, MAP kinase and Src pathways [14,15]. Very recently, we have reported that eNOS and its activity play a critical role in regulation of insulin uptake and TET as inhibition of eNOS activity completely eliminates EC insulin uptake [16]. Taken together, our studies indicate that there is the vesicular transcytotic machinery in vascular ECs that governs insulin uptake and movement through vascular ECs.

This endothelial barrier function is particularly true for skeletal muscle, a major site of fuel use, where its continuous vascular endothelium has well-developed junctional structures and abundant caveolae that provides a relatively tight diffusional barrier. This is in stark contrast to the discontinuous endothelium with gaps between

*Corresponding author: Hong Wang, Department of Medicine, University of Virginia, Box 801410, Charlottesville, VA 22908, USA, Tel: 434-924-1265; Fax: 434-924-1284; E-mail: Hw8t@virginia.edu

Received December 16, 2013; Accepted December 17, 2013; Published December 24, 2013

Citation: Wang H (2013) Traversing the Barrier: A Journey of Insulin from Vascular Lumen into Skeletal Muscle. J Metabolic Synd 3: e108. doi:10.4172/21670943.1000e108

Copyright: (C) 2013 Wang $H$. This is an open-access article distributed under the terms of the Creative Commons Attribution License, which permits unrestricted use, distribution, and reproduction in any medium, provided the original author and source are credited. 
Citation: Wang H (2013) Traversing the Barrier: A Journey of Insulin from Vascular Lumen into Skeletal Muscle. J Metabolic Synd 3: e108. doi:10.4172/2167-0943.1000e108

Page 2 of 3

vascular ECs in liver. Muscle's tight endothelium has constituted the structural basis for a strong argument that the transit of insulin from the vascular lumen to the interstitial compartment within skeletal muscle is rate limiting for insulin's metabolic action [27]. In an early study comparing the kinetics of insulin action on peripheral glucose disposal during the insulin clamp between lean and obese subjects, it was found that although hepatic glucose output was suppressed rapidly $\left(\mathrm{t}^{1} \frac{2}{2} \sim 20 \mathrm{~min}\right)$ and did not differ between normal and insulin resistant subjects, the $t^{1 / 2}$ for stimulation of whole body glucose disposal was quicker ( $44 \mathrm{~min})$ in lean adults than obese insulin resistant subjects $(\sim 74 \mathrm{~min}, \mathrm{p}<0.001)$ indicating a delay in insulin delivery into the muscle interstitium. Indeed, this rate-limiting step for peripheral insulin action is delayed in insulin-resistant obese subjects $[3,9,41,42]$.

In summary, current evidence clearly indicates that insulin TET is a transcellular process that is governed by endothelial molecular transcytotic machinery involving insulin receptor binding, activation of EC insulin signaling and membrane trafficking via caveolae. This process plays a critical role in regulation of insulin delivery into and action in the peripheral tissues under both physiological and pathophysiological conditions. Under pathophysiological conditions such as insulin resistance, obesity and type 2 diabetes, this process is significantly delayed or impaired. Better understanding complex regulatory processes and molecular mechanisms of insulin TET under a variety of disease conditions may suggest new therapeutic strategies and offer opportunities to find new intervention sites so that it will improve the treatment for insulin resistance, obesity and type 2 diabetes.

\section{Reference}

1. Yang YJ, Hope ID, Ader M, Bergman RN (1989) Insulin transport across capillaries is rate limiting for insulin action in dogs. J Clin Invest 84: 1620-1628.

2. Chiu JD, Richey JM, Harrison LN, Zuniga E, Kolka CM, et al. (2008) Direct administration of insulin into skeletal muscle reveals that the transport of insulin across the capillary endothelium limits the time course of insulin to activate glucose disposal. Diabetes 57: 828-835.

3. Castillo C, Bogardus C, Bergman R, Thuillez P, Lillioja S (1994) Interstitia insulin concentrations determine glucose uptake rates but not insulin resistance in lean and obese men. J Clin Invest 93: 10-16.

4. Yang YJ, Hope I, Ader M, Poulin RA, Bergman RN (1992) Dose-response relationship between lymph insulin and glucose uptake reveals enhanced insulin sensitivity of peripheral tissues. Diabetes 41: 241-253.

5. Sjöstrand $M$, Holmäng $A$, Lönnroth $P$ (1999) Measurement of interstitial insulin in human muscle. Am J Physiol 276: E151-154.

6. Sjöstrand M, Holmäng A, Strindberg L, Lönnroth $P$ (2000) Estimations of muscle interstitial insulin, glucose, and lactate in type 2 diabetic subjects. Am J Physiol Endocrinol Metab 279: E1097-1103.

7. Gudbjörnsdóttir S, Sjöstrand M, Strindberg L, Wahren J, Lönnroth P (2003) Direct measurements of the permeability surface area for insulin and glucose in human skeletal muscle. J Clin Endocrinol Metab 88: 4559-4564.

8. Yang YJ, Hope ID, Ader M, Bergman RN (1994) Importance of transcapillary insulin transport to dynamics of insulin action after intravenous glucose. Am J Physiol 266: E17-25.

9. Miles PD, Li S, Hart M, Romeo O, Cheng J, et al. (1998) Mechanisms of insulin resistance in experimental hyperinsulinemic dogs. J Clin Invest 101: 202-211.

10. King GL, Johnson SM (1985) Receptor-mediated transport of insulin across endothelial cells. Science 227: 1583-1586.

11. Bendayan M, Rasio EA (1996) Transport of insulin and albumin by the microvascular endothelium of the rete mirabile. J Cell Sci 109: 1857-1864.

12. Wang AX, Wang H, Barrett EJ (2010) Dynamin-2 is Critical for Vascular Endothelial Insulin Uptake. Diabetes 59(Supplement 1), A380.

13. Wang H, Wang AX, Barrett EJ (2011) Caveolin-1 is required for vascular endothelial insulin uptake. Am J Physiol Endocrinol Metab 300: E134-144.

14. Wang H, Wang AX, Barrett EJ (2012) Insulin-induced endothelial cell cortical actin filament remodeling: a requirement for trans-endothelial insulin transport. Mol Endocrinol 26: 1327-1338.

15. Wang H, Wang AX, Liu Z, Barrett EJ (2008) Insulin signaling stimulates insulin transport by bovine aortic endothelial cells. Diabetes $57: 540-547$.

16. Wang H, Wang AX, Aylor K, Barrett EJ (2013) Nitric oxide directly promotes vascular endothelial insulin transport. Diabetes 62: 4030-4042.

17. Wang H, Wang AX, Liu Z, Chai W, Barrett EJ (2009) The trafficking/interaction of eNOS and caveolin-1 induced by insulin modulates endothelial nitric oxide production. Mol Endocrinol 23: 1613-1623.

18. Wang H, Liu Z, Li G, Barrett EJ (2006) The vascular endothelial cell mediates insulin transport into skeletal muscle. Am J Physiol Endocrinol Metab 291: E323-332.

19. Bar RS, Boes M, Sandra A (1988) Vascular transport of insulin to rat cardiac muscle. Central role of the capillary endothelium. J Clin Invest 81: 1225-1233.

20. Schnitzer JE, Oh P, Pinney E, Allard J (1994) Filipin-sensitive caveolae-mediated transport in endothelium: reduced transcytosis, scavenger endocytosis, and capillary permeability of select macromolecules. J Cell Biol 127: 1217-1232.

21. Herkner $\mathrm{H}$, Klein N, Joukhadar $\mathrm{C}$, Lackner $\mathrm{E}$, Langenberger $\mathrm{H}$, et al. (2003) Transcapillary insulin transfer in human skeletal muscle. Eur J Clin Invest 33 $141-146$.

22. Eggleston EM, Jahn LA, Barrett EJ (2007) Hyperinsulinemia rapidly increase human muscle microvascular perfusion but fails to increase muscle insulin clearance: evidence that a saturable process mediates muscle insulin uptake. Diabetes 56: 2958-2963.

23. Steil GM, Ader M, Moore DM, Rebrin K, Bergman RN (1996) Transendothelia insulin transport is not saturable in vivo. No evidence for a receptor-mediated process. J Clin Invest 97: 1497-1503.

24. Hamilton-Wessler M, Ader M, Dea MK, Moore D, Loftager M, et al. (2002) Mode of transcapillary transport of insulin and insulin analog NN304 in dog hindlimb: evidence for passive diffusion. Diabetes 51: 574-582.

25. Bar RS, Boes M, Dake BL, Booth BA, Henley SA, et al. (1988) Insulin, insulinlike growth factors, and vascular endothelium. Am J Med 85: 59-70.

26. Li G, Barrett EJ, Wang H, Chai W, Liu Z (2005) Insulin at physiologica concentrations selectively activates insulin but not insulin-like growth factor (IGF-I) or insulin/IGF-I hybrid receptors in endothelial cells. Endocrinology 146 4690-4696.

27. Barrett EJ, Wang H, Upchurch CT, Liu Z (2011) Insulin regulates its own delivery to skeletal muscle by feed-forward actions on the vasculature. Am J Physiol Endocrinol Metab 301: E252-263.

28. Kolka CM, Bergman RN (2012) The barrier within: endothelial transport of hormones. Physiology (Bethesda) 27: 237-247.

29. Rothberg KG, Heuser JE, Donzell WC, Ying YS, Glenney JR, et al. (1992) Caveolin, a protein component of caveolae membrane coats. Cell 68: 673-682.

30. Siddiqui SS, Siddiqui ZK, Uddin S, Minshall RD, Malik AB (2007) p38 MAPK activation coupled to endocytosis is a determinant of endothelial monolayer integrity. Am J Physiol Lung Cell Mol Physiol 292: L114-124.

31. Minshall RD, Tiruppathi C, Vogel SM, Niles WD, Gilchrist A, et al. (2000) Endothelial cell-surface gp60 activates vesicle formation and trafficking via G(i)-coupled Src kinase signaling pathway. J Cell Biol 150: 1057-1070.

32. Couet J, Li S, Okamoto T, Ikezu T, Lisanti MP (1997) Identification of peptide and protein ligands for the caveolin-scaffolding domain. Implications for the interaction of caveolin with caveolae-associated proteins. J Biol Chem 272 6525-6533.

33. Nystrom FH, Chen H, Cong LN, Li Y, Quon MJ (1999) Caveolin-1 interacts with the insulin receptor and can differentially modulate insulin signaling in transfected Cos-7 cells and rat adipose cells. Mol Endocrinol 13: 2013-2024

34. Foti M, Porcheron G, Fournier M, Maeder C, Carpentier JL (2007) The neck of caveolae is a distinct plasma membrane subdomain that concentrates insulin receptors in 3T3-L1 adipocytes. Proc Natl Acad Sci U S A 104: 1242-1247.

35. Huo H, Guo X, Hong S, Jiang M, Liu X, et al. (2003) Lipid rafts/caveolae are essential for insulin-like growth factor-1 receptor signaling during 3T3-L1 preadipocyte differentiation induction. J Biol Chem 278: 11561-11569.

36. Goshima K, Masuda A, Owaribe K (1984) Insulin-induced formation of ruffling membranes of KB cells and its correlation with enhancement of amino acid transport. J Cell Biol 98: 801-809. 
Citation: Wang H (2013) Traversing the Barrier: A Journey of Insulin from Vascular Lumen into Skeletal Muscle. J Metabolic Synd 3: e108. doi:10.4172/2167-0943.1000e108

37. Wang Q, Bilan PJ, Tsakiridis T, Hinek A, Klip A (1998) Actin filaments participate in the relocalization of phosphatidylinositol3-kinase to glucose transportercontaining compartments and in the stimulation of glucose uptake in 3T3-L1 adipocytes. Biochem J 331: 917-928.

38. Kanzaki M, Pessin JE (2001) Insulin-stimulated GLUT4 translocation in adipocytes is dependent upon cortical actin remodeling. J Biol Chem 276 42436-42444.

39. Tong P, Khayat ZA, Huang C, Patel N, Ueyama A, et al. (2001) Insulin-induced cortical actin remodeling promotes GLUT4 insertion at muscle cell membrane ruffles. J Clin Invest 108: 371-381.
40. Pelkmans L, Püntener D, Helenius A (2002) Local actin polymerization and dynamin recruitment in SV40-induced internalization of caveolae. Science 296 : 535-539.

41. Prager R, Wallace $P$, Olefsky JM (1986) In vivo kinetics of insulin action on peripheral glucose disposal and hepatic glucose output in normal and obese subjects. J Clin Invest 78: 472-481.

42. Sjöstrand M, Gudbjörnsdottir S, Holmäng A, Lönn L, Strindberg L, et al. (2002) Delayed transcapillary transport of insulin to muscle interstitial fluid in obese subjects. Diabetes 51: 2742-2748. 